\title{
Implementasi Long Short-Term Memory Pada Harga Saham Perusahaan Perkebunan Di Indonesia
}

\author{
Rahmadi Yotenka ${ }^{1}$, Fazano Fikri El Huda ${ }^{2}$ \\ ${ }^{1}$ Prodi Statistika, Universitas Islam Indonesia, rahmadi.yotenka@uii.ac.id \\ ${ }^{2}$ Prodi Statistika, Universitas Islam Indonesia, fazanofikri@gmail.com
}

\begin{abstract}
The decline and increase in the price of shares of plantation companies is a problem for investors in making decisions to buy or sell shares. Factors influencing the movement of plantation stock prices include CPO commodity price fluctuations, world oil price fluctuations, Rupiah exchange rate fluctuations, government regulations and policies, demands from importing countries, and climate. Forecasting stock prices is expected to help investors to deal with uncertainty in the movement of plantation stock prices. This study applies the Long Short-Term Memory (LSTM) to predict the stock prices of plantation companies using SSMS, LSIP, and SIMP share price data from the period 1 July 2014 - 22 July 2019. Based on the results of the study it was found that the best LSTM model on SSMS shares by using the RMSProp optimizer and 70 hidden neurons produced an RMSE value of 21,328. Then the best LSTM model on LSIP stock by using Adam optimizer and 80 hidden neurons produces an RMSE value of 33,097. Whereas the best LSTM model on SIMP shares using Adamax optimizer and 100 hidden neurons produced an RMSE value of 8,3337 .
\end{abstract}

Keywords: Plantation, Stocks, Forecasting, Long Short-Term Memory.

\begin{abstract}
Abstrak. Penurunan dan kenaikan harga saham perusahaan perkebunan merupakan suatu masalah bagi investor dalam membuat keputusan membeli atau menjual saham. Faktor-faktor yang mempengaruhi pergerakan harga saham perkebunan diantaranya adalah fluktuasi harga komoditas CPO, fluktuasi harga minyak dunia, fluktuasi nilai tukar Rupiah, regulasi dan kebijakan pemerintah, permintaan dari negara importir, serta iklim. Peramalan harga saham diharapkan membantu investor untuk menghadapi ketidakpastian pergerakan harga saham perkebunan. Penelitian ini menerapkan Long Short-Term Memory (LSTM) untuk meramalkan harga saham perusahaan perkebunan menggunakan data harga saham SSMS, LSIP, dan SIMP dari periode 1 Juli 2014-22 Juli 2019. Berdasarkan hasil penelitian didapatkan model LSTM terbaik pada saham SSMS dengan menggunakan optimizer RMSProp dan hidden neuron sebanyak 70 menghasilkan nilai RMSE sebesar 21,328. Kemudian model LSTM terbaik pada saham LSIP dengan menggunakan optimizer Adam dan hidden neuron sebanyak 80 menghasilkan nilai RMSE sebesar 33,097. Sedangkan model LSTM terbaik pada saham SIMP dengan menggunakan optimizer Adamax dan hidden neuron sebanyak 100 menghasilkan nilai RMSE sebesar 8,337.
\end{abstract}

Kata Kunci: Perkebunan, Saham, Peramalan, Long Short-Term Memory. 


\section{Pendahuluan}

Bursa Efek Indonesia (BEI) merupakan lembaga pengelola perdagangan sekuritas terutama saham, di pasar modal Indonesia. BEI membagi saham-saham perusahaan menjadi 10 sektor usaha atau dikenal dengan indeks sektoral, salah satunya adalah sektor pertanian. Sektor pertanian merupakan sektor primer andalan BEI sebagai penyokong perekonomian nasional. BEI membagi lagi sektor pertanian menjadi tiga sub sektor yakni sub sektor tanaman, sub sektor perkebunan, dan sub sektor perikanan. Diantara ketiga sub sektor tersebut, sub sektor pekebunan merupakan sub sektor yang mendominasi pergerakan indeks saham sektor pertanian. Hal ini dikarenakan jumlah perusahaan dalam sub sektor perkebunan lebih tinggi dibandingkan jumlah perusahaan dalam sub sektor tanaman maupun perikanan [7].

Harga saham, termasuk saham sub sektor perkebunan mengandung unsur ketidakpastian, serta adanya fluktuasi yang tinggi diantaranya disebabkan oleh fluktuasi harga komoditas Crude Palm Oil (CPO), fluktuasi harga minyak dunia, fluktuasi nilai tukar Rupiah, regulasi dan kebijakan pemerintah, permintaan dari negara importir, serta iklim. Sehingga investor perlu berhati-hati dalam membuat keputusan agar tidak menimbulkan kerugian. Salah satu upaya yang dapat membantu investor dalam menghadapi ketidakpastian pergerakan harga saham adalah dengan melakukan peramalan terhadap harga saham [9].

Harga saham merupakan data time series yang memiliki dimensi yang besar, dan bersifat tidak statis. Sehingga dikembangkan pendekatan untuk data yang bersifat nonlinear [8]. Pendekatan yang bersifat nonlinear salah satunya adalah metode Artificial Neural Networks (ANN). Keuntungan utama dari ANN yaitu kemampuannya yang fleksibel dalam memodelkan nonlinier. Dengan ANN, tidak membutuhkan bentuk model tertentu yang tetap. Melainkan, model dengan adaptif dibentuk berdasarkan corak yang ditampilkan dari data [10].

Deep learning merupakan salah satu bagian dari machine learning yang menggunakan ANN dengan multi lapisan. Salah satu metode yang menggunakan teknik deep learning dalam peramalan data time series seperti harga saham adalah Long Short-Term Memory (LSTM). LSTM merupakan pengembangan dari Recurrent Neural Network (RNN) yang dipopulerkan oleh Sepp Hochreiter dan Jurgen Schmidhuber pada tahun 1997. LSTM menyimpan informasi terhadap pola-pola pada data dan dapat mempelajari data mana saja yang akan disimpan dan data mana saja yang akan dibuang. LSTM banyak digunakan untuk pemprosesan teks, video, dan data time series [1].

Penelitian ini menggunakan perusahaan perkebunan di Indonesia yang diambil dari Indeks Kompas 100 periode Februari - Juli 2019 yaitu PT Sawit Sumbermas Sarana Tbk (SSMS), PT PP London Sumatra Indonesia Tbk (LSIP), dan PT Salim Ivomas Pratama Tbk (SIMP). Dari penjelasan latar belakang dan permasalahan diatas, harga saham baik SSMS, LSIP, maupun SIMP dapat mengalami kenaikan atau penurunan yang tidak bisa dipastikan kapan waktu terjadinya. Oleh karena itu, implementasi metode LSTM digunakan untuk meramalkan harga saham SSMS, LSIP, dan SIMP. 


\section{Tinjauan Pustaka}

\subsection{Recurrent Neural Network $(R N N)$}

Recurrent Neural Network (RNN) adalah varian dari neural network yang cocok dalam pengolahan data berurutan (sekuensial). Pada umumnya, manusia tidak membuat keputusan secara tunggal setiap saat. Manusia akan selalu memperhitungkan masa lalu dalam membuat sebuah keputusan. Cara yang dilakukan RNN untuk dapat menyimpan informasi dari masa lalu adalah dengan melakukan looping di dalam arsitekturnya, yang secara otomatis membuat informasi dari masa lalu tetap tersimpan [3].

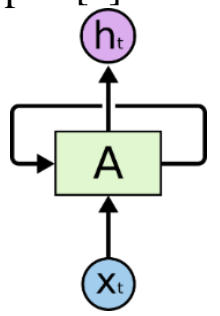

Gambar 1. Looping RNN (Olah, 2015)

Gambar 1 adalah visualisasi contoh potongan dari sebuah RNN(A). RNN tersebut mendapat input $\mathrm{X}_{\mathrm{t}}$ dan menghasilkan output $\mathrm{H}_{\mathrm{t}}$. Terdapat alur loop yang memungkinkan informasi masa lalu dapat dikirim dari satu tahap ke tahap lainnya seperti yang terlihat pada Gambar 2.

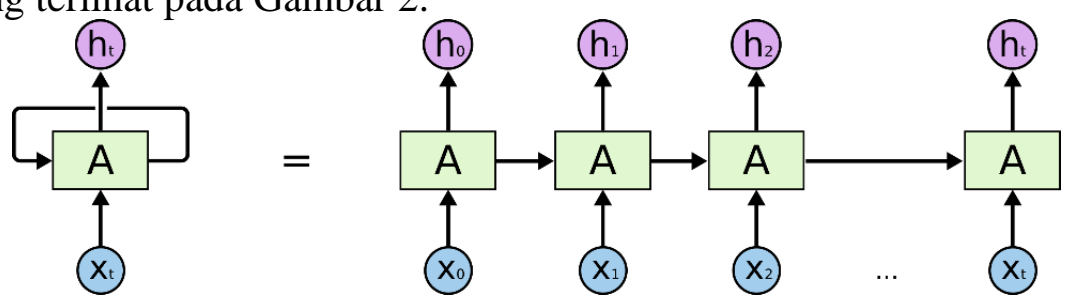

Gambar 2. Pengiriman Informasi Masa Lalu pada Looping RNN (Olah, 2015)

\subsection{Long Short-Term Memory (LSTM)}

Long Short- Term Memory (LSTM) merupakan pengembangan dari Recurrent Neural Network (RNN) yang diusulkan oleh Sepp Hochreiter dan Jurgen Schmidhuber pada tahun 1997. LSTM menyimpan informasi terhadap pola-pola pada data dengan mempelajari data mana saja yang akan disimpan dan data mana saja yang akan dibuang, karena pada setiap neuron LSTM memiliki beberapa gates (gerbang) yang mengatur memori pada setiap neuron itu sendiri. LSTM banyak digunakan untuk pemprosesan teks, video, dan data time series [1]. LSTM memiliki empat layer, yaitu forget gate (1), input gate (2), new cell state candidate (3), dan output gate (4) yang arsitekturnya terlihat pada Gambar 3. 


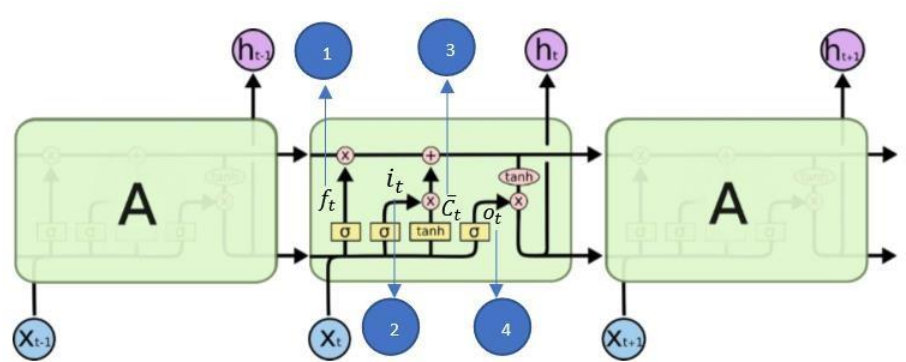

Gambar 3. Perulangan Model dengan Empat Layer pada LSTM (Winata, 2018)

Kunci utama pada LSTM adalah cell state yang menghubungkan semua output layer pada LSTM. LSTM memiliki kemampuan untuk menambah dan menghapus informasi dari cell state. Kemampuan ini disebut dengan gates. Gates sebagai pengatur apakah informasi akan diteruskan atau diberhentikan. Gates terdiri dari layer sigmoid dan pointwise multiplication operation [6].

Langkah pertama implementasi metode LSTM adalah memutuskan informasi yang akan dihapus dari cell state [11]. Keputusan ini dibuat oleh layer sigmoid yang bernama "layer forget gate". Layer forget gate akan memproses $\mathrm{h}_{\mathrm{t}-1}$ dan $\mathrm{x}_{\mathrm{t}}$ sebagai input, dan menghasilkan output berupa angka 0 sampai dengan 1 pada cell state. Persamaan forget gate diuraikan pada persamaan 1.

$$
f_{t}=\sigma\left(W_{f} \cdot\left[h_{t-1}, x_{t}\right]+b_{f}\right)
$$

Dengan $f_{t}$ merupakan forget gate, $\sigma$ adalah fungsi sigmoid, $W_{f}$ adalah nilai weight untuk forget gate, $h_{t-1}$ adalah nilai output sebelum orde ke $t, x_{t}$ adalah nilai input pada orde ke $t$, dan $b_{f}$ adalah nilai bias pada forget gate.

Langkah kedua LSTM adalah memutuskan informasi apa yang akan disimpan di cell state [11]. Untuk langkah ini terdapat dua bagian. Bagian pertama, layer sigmoid yang bernama "input gate layer" memutuskan nilai mana yang akan diperbaharui. Selanjutnya, tanh layer membuat satu kandidat dengan nilai baru, yang dapat ditambahkan ke cell state. Tahap selanjutnya adalah output dari layer input gate dan layer tanh akan digabungkan untuk memperbaruhi cell state. Formula input gate dan kandidat baru dijabarkan pada persamaan berikut.

$$
i_{t}=\sigma\left(W_{i} \cdot\left[h_{t-1}, x_{t}\right]\right)+b_{i}
$$

Dengan $i_{t}$ merupakan input gate, $W_{i}$ adalah nilai weight untuk input gate, dan $b_{i}$ adalah nilai bias pada input gate.

$$
C_{t}=\tanh \left(W_{C} \cdot\left[h_{t-1}, x_{t}\right]+b_{C}\right) \sqrt{a^{2}+b^{2}}
$$

Dengan $C_{t}$ merupakan nilai baru yang dapat ditambahkan ke cell state, $W_{i}$ adalah nilai weight untuk input gate, dan $b_{i}$ adalah nilai bias pada input gate.

Langkah ketiga adalah memperbaruhi cell state yang lama, $C_{t-1}$, menjadi cell state baru, $\mathrm{C}_{\mathrm{t}}[11]$. Formula cell state seperti pada persamaan berikut. 


$$
C_{t}=f_{t} \cdot C_{t-1}+i_{t} \cdot C_{t}
$$

Dengan $C_{t}$ merupakan cell state, $f_{t}$ adalah forget gate, $C_{t-1}$ adalah cell state sebelum orde ke $t, i_{t}$ adalah input gate, dan $C_{t}$ merupakan nilai baru yang dapat ditambahkan ke cell state.

Kemudian langkah terakhir dalam metode LSTM adalah memasukkan output dari cell state kedalam layer tanh (untuk mengganti nilai menjadi diantara -1 dan 1) dan dikalikan dengan sigmoid gate, agar output yang dihasilkan sesuai dengan apa yang diputuskan sebelumnya [11]. Formula output gate diuraikan pada persamaan berikut.

$$
o_{t}=\sigma\left(W_{o}\left[h_{t-1}, x_{t}\right]+b_{o}\right)
$$

Dengan $o_{t}$ merupakan output gate, $W_{o}$ adalah nilai weight untuk output gate, dan $b_{o}$ adalah nilai bias pada output gate. Selanjutnya nilai output orde $t$ diuraikan pada persamaan berikut.

$$
h_{t}=o_{t} \cdot \tanh \left(C_{t}\right)
$$

\subsection{Optimizer}

Optimizer bertujuan untuk menemukan bobot optimal, meminimalkan kesalahan dan memaksimalkan akurasi. Selama proses pelatihan, parameter (bobot) model diubah untuk mencoba dan meminimalkan fungsi kerugian, agar mampu memprediksi seakurat mungkin. Dalam istilah yang lebih sederhana, pengoptimalisasi membentuk model yang dimiliki ke dalam bentuk yang paling akurat dengan memanfaatkan bobotnya [2]. Adapun macam-macam optimizer antara lain adalah sebagai berikut:

1. Adaptive Moment Estimation (Adam); merupakan metode yang menghitung adaptive learning rate untuk setiap parameter. Nilai parameter yang direkomendasikan adalah $\beta_{1}=0.9, \beta_{2}=0.999$, dan $\epsilon=10^{-8}$. Dengan $\beta_{1}=\beta_{2}=$ tingkat penurunan eksponensial dan $\epsilon=$ nilai epsilon untuk update parameter [5].

2. Adamx; merupakan jenis Adam yang memiliki norma tak terhingga. Nilai parameter yang direkomendasikan adalah $\eta=0.002, \beta_{1}=0.9$, dan $\beta_{2}=0.999$. Dengan $\beta_{1}=\beta_{2}=$ tingkat penurunan eksponensial dan $\eta=$ learning rate dengan bias-correction [5].

3. RMSprop; merupakan metode yang mempertahankan moving average dari gradien kuadrat untuk setiap bobot. Nilai parameter yang direkomendasikan adalah $\eta=0.001$ dengan $\eta=$ learning rate dengan bias-correction [4].

\section{Metode Penelitian}

Data yang digunakan dalam penelitian adalah data harga saham harian SSMS, LSIP, dan SIMP periode 1 Juli 2014-22 Juli 2019. Metode analisis menggunakan Long Short-Term Memory (LSTM) yang bertujuan untuk meramalkan harga saham SSMS, LSIP, dan SIMP pada periode 23 Juli 2019-25 Juli 2019 dengan membandingkan tingkat kesalahan atau error dari beberapa model yang dibentuk. 


\section{Pembahasan}

\subsection{Grafik Pergerakan Harga Saham}

Berikut merupakan plot pergerakan harga saham SSMS, LSIP, dan SIMP yang digunakan sebagai data time series penelitian.
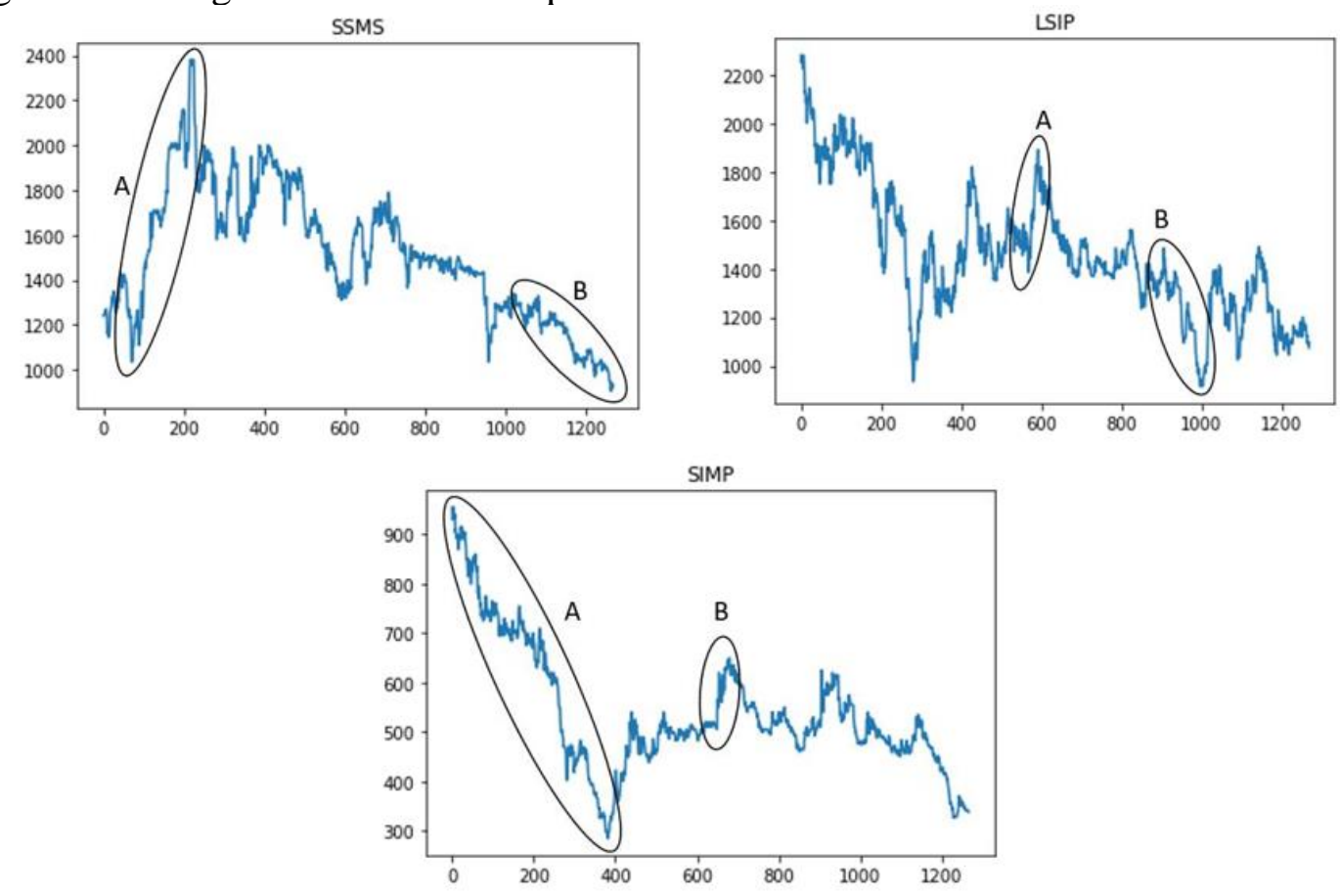

Gambar 4. Grafik Harga Saham SSMS, LSIP, dan SIMP

Berdasarkan gambar 4 diperoleh informasi bahwa pergerakan harga saham SSMS dan LSIP memiliki komponen pola siklus disertai pola trend, baik kenaikan maupun penurunan dan sangat fluktuatif. Sedangkan pergerakan harga saham SIMP juga memiliki komponen pola siklus disertai pola trend, baik kenaikan maupun penurunan. Namun tingkat fluktuatif lebih rendah daripada pergerakan harga saham SSMS danLSIP.

\subsection{Pembagian Data Training dan Testing}

Pembuatan data training dilakukan dalam rangka meningkatkan kinerja dari LSTM terhadap data testing yang akan memilih parameter terbaik untuk model. Sebanyak $80 \%$ dari total data digunakan sebagai data training dan $20 \%$ dari total data dijadikan sebagai data testing seperti yang ditunjukkan pada tabel 1. Jumlah data training lebih besar dengan tujuan agar mesin pembelajaran lebih terlatih untuk mempelajari model. Sehingga ketika mesin menghasilkan model, maka akan memberikan peramalan data testing yang lebih optimal. 
Tabel 1. Data Training dan Data Testing

\begin{tabular}{cccc}
\hline Variabel & Data Training $(\mathbf{8 0 \%})$ & Data Testing $\mathbf{( 2 0 \% )}$ & Total \\
\hline SSMS & 1.009 & 253 & 1.262 \\
LSIP & 1.010 & 253 & 1.263 \\
SIMP & 1.009 & 253 & 1.262 \\
\hline
\end{tabular}

Sumber: Peneliti

\subsection{Pemodelan Long Short-Term Memory (LSTM)}

Arsitektur jaringan LSTM dalam penelitian terdiri dari 1 input layer, 1 LSTM layer, dan 1 output layer. Kemudian parameter-parameter yang telah ditentukan adalah epoch sejumlah 250 dan batch size sejumlah 32. Optimizer pilihan dalam penelitian ini adalah Adam, Adamax, dan RMSProp. Sedangkan jumlah hidden neuron terdiri dari 10, 20, 30, 40, 50, 60, 70, 80, 90, dan 100. Pada penentuan optimizer, jumlah hidden neuron yang digunakan adalah 50. Perfoma model diukur menggunakan RMSE. Berikut hasil perhitungan RMSE menggunakan ketiga optimizer dari data harga saham SSMS, LSIP, dan SIMP.

Tabel 2. Nilai RMSE dari Variasi Optimizer

\begin{tabular}{c|c|c|c|c|c|c}
\hline \multirow{2}{*}{ Optimizer } & \multicolumn{2}{c|}{ SSMS } & \multicolumn{2}{c|}{ LSIP } & \multicolumn{2}{c}{ SIMP } \\
\cline { 2 - 7 } & $\begin{array}{c}\text { RMSE } \\
\text { Training }\end{array}$ & $\begin{array}{c}\text { RMSE } \\
\text { Testing }\end{array}$ & $\begin{array}{c}\text { RMSE } \\
\text { Training }\end{array}$ & $\begin{array}{c}\text { RMSE } \\
\text { Testing }\end{array}$ & $\begin{array}{c}\text { RMSE } \\
\text { Training }\end{array}$ & $\begin{array}{c}\text { RMSE } \\
\text { Testing }\end{array}$ \\
\hline Adam & 34,651 & 24,044 & 35,756 & $\mathbf{3 3 , 1 3 8}$ & 13,448 & 11,819 \\
Adamax & 34,648 & 23,887 & 35,486 & 33,170 & 13,130 & $\mathbf{1 0 , 9 5 1}$ \\
RMSprop & 41,306 & $\mathbf{2 1 , 7 5 6}$ & 36,357 & 35,100 & 13,291 & 11,527 \\
\hline
\end{tabular}

Sumber: Peneliti

Berdasarkan tabel 2 diperoleh informasi bahwa optimizer yang menghasilkan nilai RMSE terendah pada data testing saham SSMS, LSIP, dan SIMP masingmasing adalah RMSProp, Adam, dan Adamax. Selanjutnya adalah penentuan jumlah hidden neuron untuk pemodelan saham SSMS, LSIP, dan SIMP berdasarkan tabel 3 berikut.

Tabel 3. Nilai RMSE dari Variasi Jumlah Hidden Neuron

\begin{tabular}{c|c|c|c|c|c|c}
\hline \multirow{2}{*}{$\begin{array}{c}\text { Jumlah } \\
\text { Neuron }\end{array}$} & \multicolumn{2}{c|}{ SSMS } & \multicolumn{2}{c}{ LSIP } & \multicolumn{2}{c}{ SIMP } \\
\cline { 2 - 7 } Hidden & RMSE & RMSE & RMSE & RMSE & RMSE & RMSE \\
& Training & Testing & Training & Testing & Training & Testing \\
\hline $\mathbf{1 0}$ & 35,824 & & & & 9,735
\end{tabular}




\begin{tabular}{c|c|c|c|c|c|c}
\hline \multirow{2}{*}{$\begin{array}{c}\text { Jumlah } \\
\text { Neuron } \\
\text { Hidden }\end{array}$} & \multicolumn{2}{|c|}{ SSMS } & \multicolumn{2}{c|}{ LSIP } & \multicolumn{2}{c}{ SIMP } \\
\cline { 2 - 7 } & RMSE & $\begin{array}{c}\text { RMSE } \\
\text { Testing }\end{array}$ & $\begin{array}{c}\text { RMSE } \\
\text { Training }\end{array}$ & $\begin{array}{c}\text { RMSE } \\
\text { Testing }\end{array}$ & $\begin{array}{c}\text { RMSE } \\
\text { Training }\end{array}$ & $\begin{array}{c}\text { RMSE } \\
\text { Testing }\end{array}$ \\
\hline $\mathbf{2 0}$ & 38,788 & 23,092 & 35,402 & 33,856 & 12,566 & 9,578 \\
$\mathbf{3 0}$ & 40,076 & 21,773 & 35,245 & 33,253 & 12,760 & 10,703 \\
$\mathbf{4 0}$ & 40,585 & 22,040 & 35,566 & 33,176 & 12,947 & 10,696 \\
$\mathbf{5 0}$ & 41,306 & 21,756 & 35,756 & 33,138 & 13,130 & 10,951 \\
$\mathbf{6 0}$ & 41,491 & 21,510 & 35,980 & 33,118 & 13,402 & 11,848 \\
$\mathbf{7 0}$ & 41,753 & $\mathbf{2 1 , 3 2 8}$ & 36,168 & 33,149 & 11,605 & 8,379 \\
$\mathbf{8 0}$ & 41,448 & 21,717 & 36,004 & $\mathbf{3 3 , 0 9 7}$ & 13,420 & 11,888 \\
$\mathbf{9 0}$ & 41,861 & 21,678 & 36,208 & 33,121 & 11,708 & 8,351 \\
$\mathbf{1 0 0}$ & 42,132 & 21,546 & 36,435 & 33,125 & 11,612 & $\mathbf{8 , 3 3 7}$ \\
\hline
\end{tabular}

Sumber: Peneliti

Jumlah hidden neuron yang menghasilkan nilai RMSE terendah pada data testing saham SSMS, LSIP, dan SIMP masing-masing adalah 70, 80, dan 100.

\subsection{Peramalan Harga Saham}

Berikut adalah hasil peramalan harga saham dari ketiga perusahaan perkebunan dengan menggunakan model LSTM terbaik yang telah didapatkan sebelumnya.

Tabel 4. Hasil Peramalan dan Harga Aktual

\begin{tabular}{c|c|c|c|c|c|c}
\hline \multirow{2}{*}{ Periode } & \multicolumn{2}{c|}{ SSMS } & \multicolumn{2}{c}{ LSIP } & \multicolumn{2}{c}{ SIMP } \\
\cline { 2 - 7 } & $\begin{array}{c}\text { Harga } \\
\text { Peramalan }\end{array}$ & $\begin{array}{c}\text { Harga } \\
\text { Aktual }\end{array}$ & $\begin{array}{c}\text { Harga } \\
\text { Peramalan }\end{array}$ & $\begin{array}{c}\text { Harga } \\
\text { Aktual }\end{array}$ & $\begin{array}{c}\text { Harga } \\
\text { Peramalan }\end{array}$ & $\begin{array}{c}\text { Harga } \\
\text { Aktual }\end{array}$ \\
\hline 23 Juli 2019 & 942,31 & 915 & $1.122,68$ & 1.085 & 351,56 & 338 \\
24 Juli 2019 & 954,61 & 915 & $1.130,80$ & 1.1 & 355,27 & 348 \\
25 Juli 2019 & 966,57 & 965 & $1.138,12$ & 1.095 & 358,87 & 350 \\
\hline
\end{tabular}

Sumber: Peneliti

Kemudian ditunjukkan grafik perbandingan antara data aktual harga saham harian SSMS, LSIP, dan SIMP dengan hasil peramalan harga saham harian SSMS, LSIP, dan SIMP menggunakan model LSTM terbaik. 

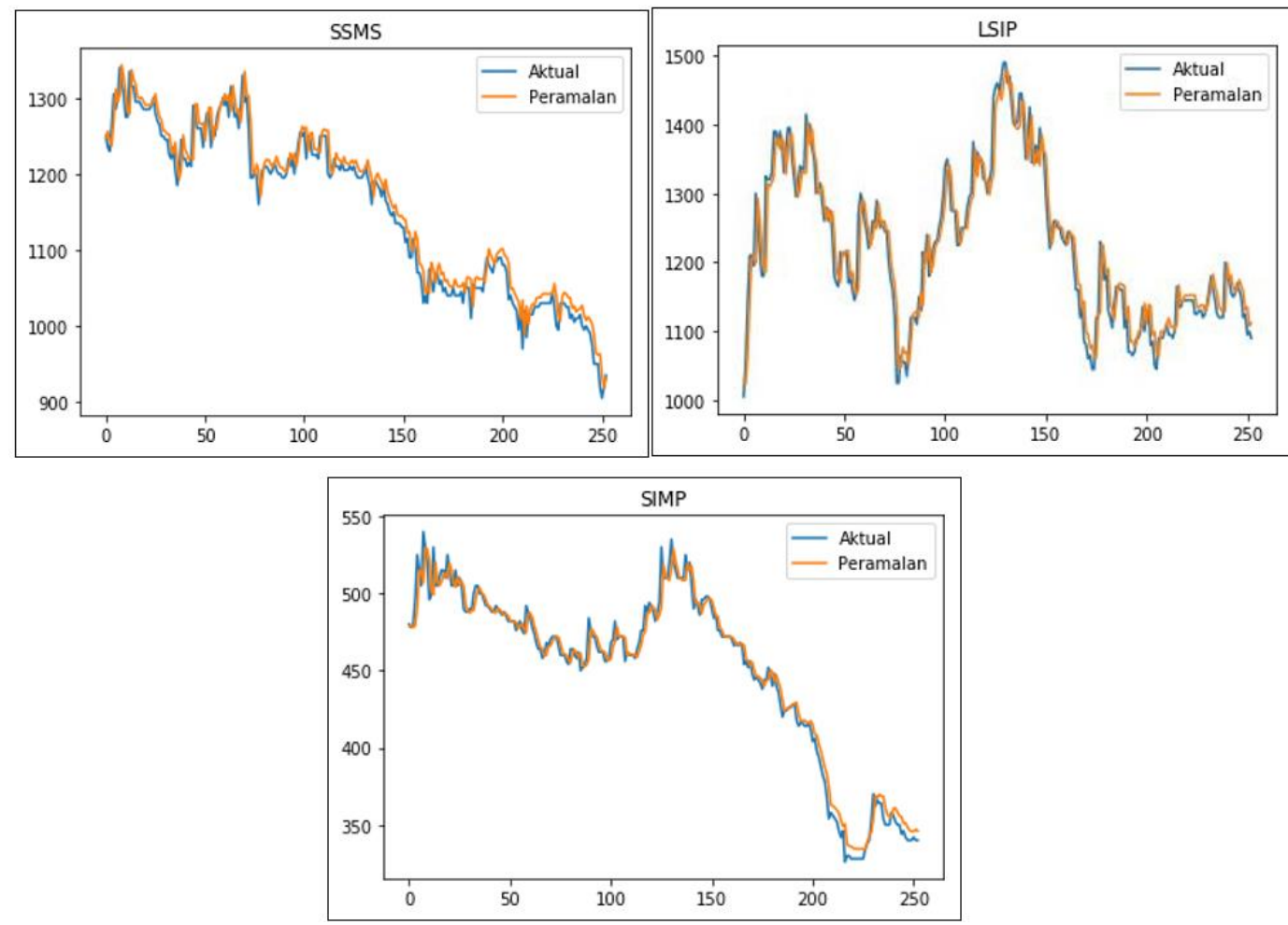

Gambar 5. Grafik Perbandingan Data Aktual dan Hasil Peramalan

Dari gambar 5 terlihat bahwa plot data hasil peramalan menggunakan metode LSTM memiliki bentuk yang mengikuti plot data harga penutupan saham harian SSMS, LSIP, dan SIMP aktual.

\section{Kesimpulan}

Berdasarkan hasil penentuan optimizer dan jumlah hidden neuron, model LSTM terbaik untuk meramalkan harga saham harian SSMS, LSIP, dan SIMP masing-masing adalah menggunakan optimizer RMSProp dengan jumlah hidden neuron 70, optimizer Adam dengan jumlah hidden neuron 80, dan optimizer Adamax dengan jumlah hidden neuron 100.

Dari hasil peramalan diperkirakan bahwa harga saham SSMS akan mengalami kenaikan sampai dengan harga Rp966,57/lembar pada 25 Juli 2019. Begitu juga harga saham LSIP dan SIMP diperkirakan akan mengalami kenaikan masingmasing Rp1.138,12/lembar dan Rp 358,87/lembar pada 25 Juli 2019.

\section{Daftar Pustaka}

[1] Aldi, M. W., Jondri, dan Aditsania, A. 2018. Analisis dan Implementasi Long Short Term Memory Neural Network untuk Prediksi Harga Bitcoin. eProceeding of Engineering, 3548-3555.

[2] Donges, N. 2018. Towards Data Science. Diambil kembali dari Gradient Descent in a Nutshell: https://towardsdatascience.com/gradient-descent-in-a- 
nutshell-eaf8c18212f0

[3] Gema, A. P., dan Suhartono, D. 2017. Recurrent Neural Network (RNN) dan Gated Recurrent Unit(GRU). Binus

[4] Hinton, G., Srivastava, N., \& Swersky, K. 2012. Neural Networks for Machine Learning Lecture 6a Overview of Mini-batch Gradient Descent. University of Toronto. Canada

[5] Kingma, D. P., dan Ba, J. L. 2015. Adam: A Method for Stochastic Optimization. The 3rd International Conference for Learning Representations, (hal. 1-15). San Diego.

[6] Olah, C. 2015. Understanding LSTM Networks. Diambil kembali dari https://colah.github.io/posts/2015-08-Understanding-LSTMs/.

[7] Rachmat, M. P. 2017. Pengaruh Financial Leverage Dan Profitabilitas Terhadap Harga Saham. Universitas Pendidikan Indonesia. Bandung.

[8] Siahaan, L. E., Umbara, R. F., dan Sibaroni, Y. 2017. Prediksi Indeks Harga Saham dengan Metode Gabungan Support Vector Regression dan Jaringan Syaraf Tiruan. IndoJC, 21-30.

[9] Sismi, dan Darsyah, M. Y. 2018. Perbandingan Prediksi Harga Saham PT. BRI, Tbk dengan Metode ARIMA dan Moving Average. Prosiding Seminar Nasional Mahasiswa Unimus, 351-360.

[10]Wang, X., dan Meng, M. 2012. A Hybrid Neural Network and ARIMA Model for Energy Consumption Forecasting. Journal of Computers, 1184-1190.

[11]Winata, W. 2018. Prakiraan Suhu Udara Rata-Rata Kota-Kota Besar Dunia Menggunakan Metode Long Short-Term Memory. Universitas Sumatera Utara. Medan. 